\title{
Accreditation Practices in Psychological Counseling and Guidance
}

\author{
Serdar Körük ${ }^{1}$
}

\begin{abstract}
The purpose of this review is to investigate the practices of accreditation in the field of psychological counseling and guidance. In this study, the training processes in psychological counseling and guidance was searched in both Turkey and other countries. Institutions that form the accreditations for psychological counseling profession in both undergraduate, graduate, doctorate and professional career have been examined. Information on the practises of CACREP (Council for the Accreditation of Counseling and Related Educational Programs) and EAC (The European Association for Counseling), which are competent associations for accreditation, are given. In Turkey, the activities of many years of work that the Turkish Psychological Counseling and Guidance Association have tried to conduct on the accreditation of psychological counselor education were indicated. Lastly, new accreditation models which can be applied in the education process of psychological counseling and guidance in undergraduate, graduate and doctoral levels in Turkey were discussed.
\end{abstract}

Keywords: Psychological Counseling, Accreditation, Education, Turkey

\section{INTRODUCTION}

The first steps taken in psychological counseling and guidance in Turkey began in the 1950s. In the same years, psychological counseling and guidance have gained importance in the United States (Doğan, 2000). In the 1950s, in the area of school counseling, the experts came to Turkey from the United States, said that as a starting point for psychological counseling and guidance in our country. Psychological counseling and guidance undergraduate programs in our country were first opened in 1982 and graduates are assigned to schools and institutions affiliated to the Ministry of National Education since 1996 as a school psychological counselor (Korkut, 2007).

The psychological counseling profession in our country shows differences in some points compared to other countries in the professional context. In many developed countries, psychological counseling education is given considering specialization areas at graduate and doctoral levels. In Turkey, psychological counseling education is given at undergraduate, graduate and doctoral levels and there is no specialization area. Similarly, in many developed countries, counselors who have completed masters and doctoral studies in the field of psychological counseling can work by completing the professional career accreditations of different institutions according to their fields of specialization. In Turkey, after receiving undergraduate education in psychological counseling, counselors mostly work in government schools serving as school counselors. Once psychological counselors get into the professional working life in Turkey, their counseling or other professional practices are not supervised or accredited by any official government and private sector institution as in the undergraduate, graduate, and doctoral education period.

\footnotetext{
${ }^{1}$ Res.Assist., Eskişehir Osmangazi University, Faculty of Educational Sciences, serdarkoruk1989@gmail.com
} 
Provision of professional standards and accreditation in psychological counseling training are the most important requirements so that the profession can be done professionally (Sweeney, 1995). Accreditation is defined as a process by which a professional association or private organization confirms a vocational training program or an educational institution that meets certain standards and qualifications as a result of periodic assessments (Altekruse \& Wittmer, 1991). Two types of accreditation models are generally applied. In the institutional accreditation model, an accrediting committee established within the university or faculty is accrediting all related units of the university or faculty. In the specialist accreditation model, accreditation is given to an academic institution or vocational training program that provides specific knowledge and skills by a professional association or private organization. There are two major professional institutions named EAC in Europe and CACREP in the United States which conduct specialist accreditation in the field of psychological counseling and guidance. Analyzing the accreditation practices conducted in the world and adapting them to the existing system in our country will contribute to the development of the field of psychological counseling in Turkey.

\section{CACREP and EAC}

In the United States, CACREP is the most authoritative institution that sets standards and accreditations in psychological counseling education (Council for the Accreditation of Counseling and Related Educational Programs). This institution determines the accreditation of psychological counseling education according to the model of specialist accreditation. CACREP was founded in 1981 and has completed accreditation of 228 institutes and 500 programs by 2009 (CACREP, 2009). CACREP examines accreditations in various sections. The first part is the learning environment. In this section, the accreditations about the institute, academic unit, faculty and staff providing psychological counseling education are explained. According to the content of this section, counselors who specialize in various subfields of psychological counseling (addiction counseling, clinical counseling, rehabilitation counseling, marriage, couple and family counseling, school counseling) are required to take a minimum of 60 credit hours per semester. The second part of CACREP's accreditation list is the professional identity of a psychological counselor. The most important point in this section is the basic themes that any psychological counseling curricula should have. Regardless of which counseling subfield, eight core areas must be in curricula. These; professional counseling orientation and ethics, social and cultural diversity, human development, career development, counseling and human relationships, group counseling and group work, measurement and testing practice, research and program development. When examining the courses in the psychological counseling and guidance undergraduate programs in Turkey, it is possible to see these eight main themes in general. The third part of the accreditation is professional practice. This section explains the accreditation of the trainees for psychological counseling practices and internships. Students who are continuing their education in any branch of psychological counseling should conduct for a minimum of 100 hours counseling under supervision in an academic year. A minimum of 40 hours of this 100 hour counseling sessions must be with the clients who have applied for a psychological counseling center. Students who complete these accreditations are entitled to internship. In order to complete the internship, it is necessary to conduct for 600 hours counseling under supervision and 240 hours of these 600 hours must be done directly in the psychological counseling center. Students who receive psychological counseling education at undergraduate, masters and doctoral level in Turkey are similarly obliged to conduct psychological counseling sessions under 
supervision but accreditations differ according to the related faculties and institutes since the accreditations required to be completed are not determined by a national official institution. CACREP accredits school psychological counseling, career counseling, college psychological counseling, community psychological counseling, geriatric psychological counseling, marriage and couple counseling, mental health counseling, psychological counseling training and supervision programs. The audio and video records of the counseling sessions should be taken and analyzed in the supervision. Based on the faculties, institutes and institutions that provide psychological counseling education, the number of supervisees per supervisor should be six at most. It is explained that the work load is the most likely to be this way. CACREP's accreditations are specialist accreditations. However, any institution that provides psychological counseling education can create its own institutional accreditations.

EAC (The European Association for Counseling) is the accreditation and standardization committee in the field of psychological counseling within the European Union. Although this association is not as advanced as CACREP, it continues accreditation works. The EAC's accreditation in psychological counseling training is as follows; a minimum of 450 hours of theoretical lecture including personal development, theories and skills, minimum 50 hours of individual therapy participation by the supervisee himself / herself, 100 hours of counseling sessions conducted by the supervisee according to the specialization area, completion of the program and 450 hours of professional counseling application under supervision after graduation. According to EAC standards, psychological counseling training lasts for 3-6 years. The psychological counseling curriculum should include the following elements: counseling theories, personality theories, theories of development, psychological disorders, psychological counseling and ethics, history of psychological counseling and cultural differences. Related information to CACREP and EAC is given in Table 1. 
Table 1.

CACREP and EAC Accreditations

\begin{tabular}{|c|c|c|c|}
\hline Institution & Training Requirements & $\begin{array}{l}\text { Counseling } \\
\text { Curriculum }\end{array}$ & $\begin{array}{l}\text { Professional } \\
\text { Accreditation }\end{array}$ \\
\hline \multirow[t]{2}{*}{ EAC } & $\begin{array}{l}450 \text { hours of course work including } \\
\text { personal development, theory and skills } \\
\text { A minimum of } 50 \text { hours of personal } \\
\text { therapy consistent with the model of } \\
\text { practice } \\
100 \text { hours of supervised counseling } \\
\text { practice during training }\end{array}$ & $\begin{array}{l}\text { Clear } \\
\text { understanding of a } \\
\text { core theoretical } \\
\text { model of } \\
\text { counselling } \\
\text { Theories of } \\
\text { personality } \\
\text { Theories of } \\
\text { change or client } \\
\text { movement } \\
\text { Models of human } \\
\text { development } \\
\text { Understanding of } \\
\text { psychological } \\
\text { dysfunction } \\
\text { Understanding of } \\
\text { ethics and } \\
\text { professional } \\
\text { practice } \\
\text { The history of } \\
\text { counselling and a } \\
\text { study of at least } \\
\text { two other } \\
\text { counselling } \\
\text { approaches } \\
\text { Study of cultural } \\
\text { differences and } \\
\text { awareness } \\
\text { processes }\end{array}$ & $\begin{array}{l}\text { An extra } 450 \text { hours } \\
\text { under supervision after } \\
\text { qualification while } \\
\text { working towards } \\
\text { professional } \\
\text { accreditation }\end{array}$ \\
\hline & $\begin{array}{l}\text { Entry-level degree specialty areas in } \\
\text { addiction counseling; clinical mental } \\
\text { health counseling; clinical rehabilitation } \\
\text { counseling; and marriage, couple, and } \\
\text { family counseling consists of approved, }\end{array}$ & $\begin{array}{l}\text { Professional } \\
\text { counseling } \\
\text { orientation and } \\
\text { ethical practice } \\
\text { Social and cultural }\end{array}$ & $\begin{array}{l}600 \text { hours counseling } \\
\text { under supervision and } \\
240 \text { hours of these } 600 \\
\text { hours must be done } \\
\text { directly in the } \\
\text { psychological }\end{array}$ \\
\hline
\end{tabular}




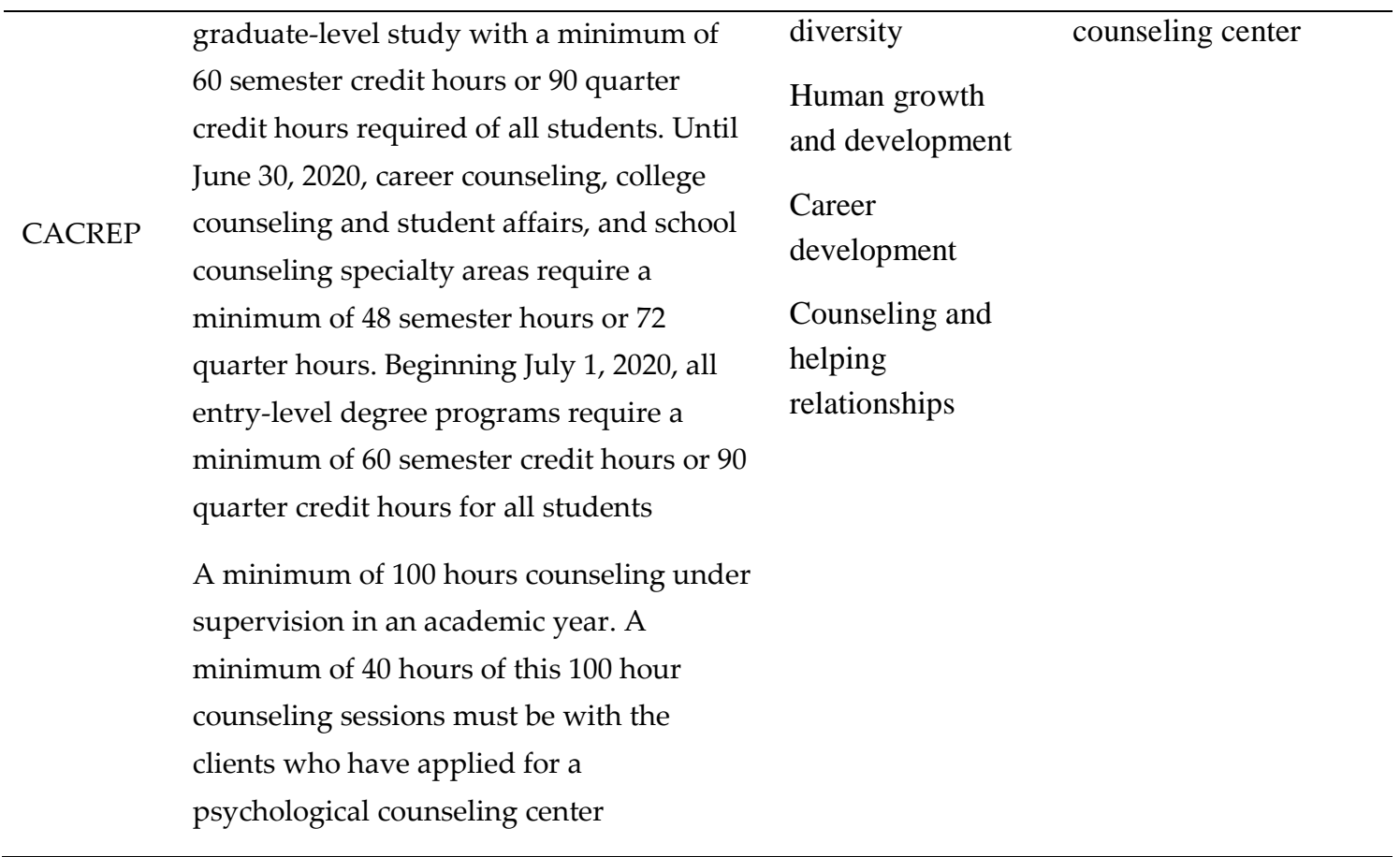

\section{Psychological Counseling Education in Turkey}

In Turkey, an accreditation problem is experienced in both psychological counseling training programs and professional life. There is no officially accredited certificate program, or undergraduate, graduate or doctoral degree content to be a professional psychological counselor. Psychological counseling education is provided by undergraduate programs of education faculties of universities (Dogan, 1998). Many universities also offer graduate and doctoral programs. In psychological counseling education in Turkey, in all three levels of education, unlike many other countries, a specialization of branches does not exist. The Turkish Psychological Counseling and Guidance Association have been working for a long time in order to provide accreditation and professionalization in this area in our country. In 1995, the association first tried to establish a standard in this area by publishing ethical standards in the field of psychological counseling. Psychological counseling degree programs in Turkey generally contain 240 ECTS theoretical and practical courses. The students', who take the individual counseling practice course in the last grade of the university, practices differ according to the universities and there is no accreditation in this respect. Doğan (2016) describes a model that can be accredited for undergraduate, graduate and doctoral levels in psychological counseling education. Undergraduate education will focus on school psychological counseling and will include a program of 140-150 credits. Students will begin to take various elective courses in the fifth semester, together with the lessons in the school counseling and practice / internship courses. 100-150 hours, which is necessary for psychological counseling practice and 200-250 hours is required for institutional practice. Four professional areas are indicated in the master's degree education; school counseling, family and marriage counseling, community mental health counseling, and career counseling. Graduate programs must have a minimum of 48 credits and the faculties must seek admission to the graduate qualification for at least two years' experience in the 
field of psychological counseling. In PhD education, it is necessary to have graduate degree as an entrance condition and to have provided counseling services for at least five years in the field of psychological counseling. PhD education should consist of at least 60 credits and should include 400-450 hours of practice / internship.

In addition to psychological counseling programs in the United States, there are various accreditations in entry to institutions that can be worked after graduation. For example, in order to become a manager in the psychological counseling centers in the universities, there is a requirement to complete doctoral thesis in one of the fields of psychological counseling, clinical psychology or other counseling fields, and to have provided professional counseling service for at least three years. Other professionals working in the same institution should have a master's degree from at least one of the fields of psychological counseling, have received supervision and have taken courses in psychopathology, personality theories, human development, learning theories, psychological counseling theories and psychological tests (Boyd et al., 2003). When the situation in our country is examined, it is seen that there is no accreditation of labor. Individuals who have completed a psychological counseling and guidance undergraduate degree program can work in public schools as school psychological counselors; they work as psychological counselors in guidance and research centers and universities, and as pedagogues in courthouses. Psychological counseling and guidance centers located in universities can add to their job advertisements the condition of being a graduate in some cases.

\section{DISCUSSION}

This review article is written to examine the accreditation practices in psychological counseling and guidance. In the world, specified and professional accreditation practices applied by the institutions found to have, in Turkey, there is no accreditation practices applied in the specified level. The training of mental health related areas in accordance with certain norms and the evaluation of individuals working in the mental health field according to certain norms are of great importance both in terms of community health and professional identity. For these reasons, In Turkey, it is vitally necessary to form legal and official accreditation norms which The Turkish Psychological Counseling and Guidance Association, academicians, and The Turkish Ministry of Education should jointly create and which can be applied both the undergraduate, graduate, and doctoral education process in universities and the professional career.

\section{REFERENCES}

Altekruse, M. K., \& Wittmer, J. (1991). Accreditation in counselor education. In F. O. Bradley (Ed.), Credentialing in counseling, (pp. 53-62). Alexandria, VA: ACES.

Boyd, V., Hattauer, E., Brandel, I. W., \& Buckles, N. (2003). Accreditation standards for university and college counseling centers. Journal of Counseling and Development: JCD, 81(2), 168-178.

Council for the Accreditation of Counseling and Related Educational Programs (CACREP). (2009). Accreditation standards. 
Dogan, S. (1998). Counseling in Turkey: Current status and future challenges. Education Policy Analysis Archives, 6, 1-12.

Dogan, S. (2000). The historical development of counseling in Turkey. International Journal for the Advancement of Counselling, 22(1), 57-67.

Doğan, S. (2016). The need for accreditation in counselor education: A recommended model. Turkish Psychological Counseling and Guidance Journal, 2(14), 31-38.

Korkut, F. (2007). Counselor education, program accreditation and counselor credentialing in Turkey. International Journal for the Advancement of Counselling, 29(1), 11-20.

Sweeney, T. J. (1995). Accreditation, credentialing, professionalization: The role of specialties. Journal of Counseling and Development: JCD, 74(2), 117-226. 